\title{
Mind the gap: bridging feminist and political geography through geopolitics
}

\author{
Jennifer Hyndman *
}

Department of Geography, Simon Fraser University, 8888 University Dr., Burnaby, BC, Canada

\begin{abstract}
The intersections and conversations between feminist geography and political geography have been surprisingly few. Feminist geographers' forays into geopolitics and international relations within political geography have been relatively rare compared to their presence and influence in social, cultural, and economic geography. Likewise, only a few political geographers concerned with IR and geopolitics have engaged with scholarship in feminist geography. In an attempt to traverse this gap, the notion of a feminist geopolitics is elaborated; it aims to bridge scholarship in feminist and political geography by creating a theoretical and political space in which geopolitics becomes a more gendered and racialized project, one that is epistemologically situated and embodied in its conception of security. Building upon scholarship in critical geopolitics, feminist international relations, and transnational feminist studies, a theoretical framework for feminist geopolitics is sketched in the first part of the paper. Feminist geopolitics represents more accountable and embodied political responses to international relations at multiple scales. Its application to pressing issues of security and mobility is illustrated in the second half of the article.
\end{abstract}

Keywords: Feminist geography; Political geography; Geopolitics; Scale; Security

\section{Introduction}

Geographers who find themselves at the crossroads of feminist and political geography have lamented the paucity of scholarship that links the two (Kofman \& Peake, 1990; Staeheli, 1999). Despite on-going work to advance a thoroughly feminist political geography (Staeheli, Kofman, \& Peake, 2004), the intersections

${ }^{*}$ Tel.: +1-604-291-5464; fax: +1-604-291-5841.

E-mail address: hyndman@sfu.ca (J. Hyndman). 
between these two sub-disciplines are relative few, particularly in relation to geopolitics. I aim to strengthen these connections in this paper by making the case for a feminist geopolitics, one comprised of an embodied view from which to analyze visceral conceptions of violence, security, and mobility. While the state remains a vital subject of interrogation in relation to security, it obscures fear and violence at other scales, beyond its purview.

Feminist geography has undergone several transformations since its inception in the late 1970s and early 1980s. A largely Anglo-North American socialist feminist geography has not proven analytically powerful enough to incorporate social relations produced through differences beyond those of gender and class. A cultural turn in feminist geography has shifted more attention to spatialized processes of racialization and racism, highlighting the ways in which space and social relations are mutually constituted (Kobayashi \& Peake, 1994). The rise of postcolonial feminisms, and what have been referred to as "feminist geographies of difference," mark a cultural turn in geography since the late 1980s (Pratt, 2000). Given the dearth of feminist geographical analysis on international relations (IR), the case for a political turn in feminist geography has been made (Hyndman, 2001). Feminist geography is already inherently political in that it advocates change where social, economic, or political relations, including those of gender, are inequitable, violent, or exploitative. This political turn, however, aims to synthesize the small "p" political of feminist geography with the larger " $P$ " political of political geography.

The main focus of this paper is not to develop further the "political" within feminist geography, but to establish common terrain between elements of feminist and political geography and generate grounds for applying feminist geopolitics as an analytical approach. I focus on feminist geopolitics at multiple scales, but without assuming that scale is pre-given or discrete as spatial units of analysis. The article provides a theoretical framework and concrete illustrations of what a feminist geopolitics might look like and how it can be done. A feminist geopolitics attends to unprecedented transnational economic integration, political transformation, and social dislocation (Dowler \& Sharp, 2001). In what follows, feminist geopolitics aims to forge more accountable and material conceptions and scales of security.

Two tasks are central to the articulation of feminist geopolitics. First, I outline a theoretical framework that builds upon three diverse, extant literatures: critical geopolitics, feminist perspectives on international relations, and transnational feminist studies. Following Simon Dalby, I take critical geopolitics to be a recent radical school of geopolitics that refers not to a new theory of geography and politics, but is "broadly understood as the critical and poststructuralist intellectual practices of unraveling and deconstructing geographical and related disguises, dissimulations, and rationalizations of power" (Dalby, 1994: p. 595; see also Ó Tuathail, 1998). As Dalby (2003: p. 4) cautions, "recent debates under the rubric of critical geopolitics are always in danger of becoming discussions of social science method rather than engagements with politics, discussions of the relative merits of various theorists rather than critiques of the geopolitical reasoning in vogue in world politics." I contend that the synthesis of critical geopolitics with feminist politics 
galvanizes this political engagement and strengthens the project of critically assessing dominant geopolitical discourses.

Feminist geopolitics aims to extend the work of arguably disembodied critical geopolitical analysis by (re)situating knowledge production as a partial view from somewhere (Haraway, 1991; Sparke, 2000).

There is no way to 'be' simultaneously in all, or wholly in any, of the privileged (subjugated) positions structured by gender, race, nation, and class... an optics is a politics of positioning (Haraway, 1991: p. 193).

Situating knowledge is the key practice grounding the imagery of vision, particularly cartographies of geopolitical alliance and enmity. Feminist geopolitics then includes embodied epistemologies and the security, or protection, of people. Embodied vision, that is to say ontologically committed, partial perspectives, may have the potential to subvert dominant geopolitical narratives, actions that might have concrete effects on the lives of people who are players in such events. Feminist geopolitics is distinguished from critical geopolitics by adding a potentially reconstructive political dimension to the crucial but at times unsatisfactory deconstructionist political impulses. In the second part of the paper, I sketch several ways in which feminist geopolitics has been brought to bear on conventional discourses of geopolitics and international relations.

The term "feminist" is employed in a broad and inclusive sense to describe analyses and political interventions that address the asymmetrical and often violent relationships among people based on real or perceived social and cultural differences. Just as there are several schools of thought within political geography, there are many feminisms, and this paper does not attempt to fix the term "feminist" in any singular manner. Gender remains a central concern of feminist politics and thought, but its primacy over other positionings is not fixed across time and place. Asymmetrical gender relations that position women as subordinate to men exist across space and time, but it would be ethnocentric, if not racist, to assume that gender is always and everywhere the primary basis of oppression, persecution, or exclusion (Anzaldua, 1987; Mohanty, 1991). Relations of class, race, caste, sexuality, religion, nationality, ethnicity, and other axes of affiliation are potentially exclusionary, discriminatory, and even violent. And while disparities based on these differences are in themselves important, it is the prevailing power relations and discursive practices that position groups of people in hierarchical relations to others based on such differences that remain critical to this feminist analysis. Building on critiques from both political geography and political science, feminist geopolitics decentres but does not dismiss state security, the conventional subject of geopolitics, and contests the militarization of states and societies (Falk, 2000). It attempts to develop a politics of security at the scale of the (civilian) body.

A feminist geopolitical imagination aims to remap realist geopolitics by interrogating scale as pre-given and discrete from other levels of analysis. The invocation of scale is critical in structuring political action (Staeheli, 1994), yet it is historically produced, variegated, and contested (Swyngedouw, 2000). Rethinking 
scale entails more than deconstructing dominant geopolitical narratives; it involves engaging relationally with processes that are made powerful by the existence of borders, or that appear to exist beyond borders. International borders can serve to naturalize difference, refuse political alliances, and obscure commonalities between discrete spaces and linked oppression. Spivak's (1990) work urges us to connect local contingencies with the operation of power across borders that construct and reify difference. Studying mobility across such borders represents one tool for problematizing scale and foregrounding power relations that include, but exceed, the borders of nation-states. The analytical and political valence of deploying feminist geopolitics in relation to mobility, violence, and security is explored in the second half of the paper. By analyzing state power at a multiplicity of scales and focusing on embodied epistemologies and subjects, geographers can begin to forge a bridge between political and feminist geography.

\section{Querying geopolitics}

Taylor (2000) has referred to geopolitics as the least problematized aspect of geographical knowledge, tacitly underwritten by Cold War strategy and "real world" political concerns (Agnew, 2003). The emergence of "critical geopolitics" in political geography and political science coincides with the end of the bipolar division of superpowers and their allies. Influenced by poststructuralism and responding to the realist approaches of international relations in conventional geopolitical discourse, critical geopolitics has not simply contested the claims of IR theory and international political economy (IPE), but taken them apart by exposing the assumptions of each and challenging their taken for granted categories of analysis. Critical geopolitics challenges the commonsense understandings and practices of "peace", "violence", and "war" within the state system (Dalby, 1991), and situates power not in the hands of a sovereign state or individual, but in more relational ways that traverse a spectrum of scales of social life (Sparke, 1998).

\section{Critical geopolitics}

Within geography, "[c]ritical geopolitics is one of many cultures of resistance to Geography as imperial truth, state-capitalized knowledge, and military weapon. It is a small part of a much larger rainbow struggle to decolonize our inherited geographical imagination so that other geo-graphings and other worlds might be possible" (Ó Tuathail, 1996a: p. 256; see also Dalby, 2003). This aspiration to create other possible worlds overlaps with the project of feminist geopolitics. The value of critical geopolitics is more questionable if it provides few clues for "seeing" in other ways.

Ó Tuathail's (1996a) exegesis, Critical Geopolitics, provides compelling critiques of geopolitics, but by remaining separate from other epistemological ways of knowing how to "geograph" the world or from ontological commitments to it, critical geopolitics becomes disembodied critical practice that suffers from "a 
dearth of commentary on the prospects for resistance" (Sparke, 2000: p. 378). While arguing against positions that are unmarked, unmediated, and transcendent, Ó Tuathail unwittingly becomes part of this category. At some level, the author reproduces geopolitics as masculinist practice by focusing his work on the "history of Big Men", from Mackinder to Spykman (Sharp, 2000a: p. 363). To his credit, O Tuathail (1996b) also provides a road map out of this tight spot by tracing the reportage of Maggie O'Kane, an Irish journalist whose visceral dispatches from the frontlines of the war in Bosnia-Herzegovina represent a kind of feminist geopolitics at work. I shall return to O'Kane's reporting in the second part of this paper, and note here only that O'Kane's journalism is highly personal and embodied in its representation of conflict. "These are [knowledge] claims on people's lives; the view from a body, always a complex, contradictory, structuring and structured body, versus the view from above, from nowhere, from simplicity" (Haraway, 1991: p. 195). How, then, can dominant scripts of geopolitics be both displaced and re-situated in order to foreground the security of people on the ground, those subjects effaced by realist geopolitics and international relations?

A number of geographers have mobilized critical geopolitics in a manner that bespeaks a concomitant critical and/or feminist politics (Sparke, 1996; Sharp, 2000b). Tesfahuney (1998) deploys critical geopolitics to expose the construction of migrants as a threat and to address the racialization, criminalization and securitization of regimes to manage international migration. Routledge (1996) uses a study of social movements in South Asia to examine the critical ways in which they challenge state-centered notions of hegemony. "A critical geopolitics can attempt to tell stories of resistance that traverse between and within sites of resistance... Critical engagement opens up a legitimate space for practical actions: heterogeneous, fragmented, polyvalent, a multiplicity of resistances" (Routledge, 1996: p. 528). Despite or perhaps because of its ontological investments, Routledge retains the possibility of resistance and action by arguing that such change is scripted in more ways than one. His tales of subversion, conflict, and change permit the players he describes to "do something" about their situation, without subscribing to a single authoritative narrative.

Routledge also draws upon feminist reflexivity and a "relational ethics" to analyze the politics of his research "in the field". Relational ethics for Routledge (2002: p. 487) mean "to work with the differences between collaborators, searching for mutual understanding... Difference is not denied, essentialized, or exoticised, but rather engaged with in an enabling and transformative way." His situated and embodied account of the politics of posing as a tourism representative in Goa, India, as a means to collaborate with two local environmental organizations resisting tourism development, exposes the messiness of resistance as a political strategy and research method. Within the context of political struggles, notes Routledge, researchers take sides, albeit in a critical way.

A decade ago, Dalby (1994) noted the lack of attention to gender at the intersection of IR theory and critical geopolitics, reiterating issues long raised by feminists in both geography (Kofman \& Peake, 1990; Staeheli, 1994) and political science (Peterson, 1992; Whitworth, 1994). Following feminists in IR, he examined 
the ways in which geopolitical categories of security are gendered and of the gender-blind analysis of much IR theory. His overview of gender and feminism in IR underscores the dearth of feminist voices in this area of geography with notable exceptions. Dalby asks us to mind the gap, one that remains in place today despite important interventions by feminist political geographers who straddle the divide (Kofman, 1996; Sharp, 1996a,b, 2000b). Critical geopolitics is a useful departure point and antecedent to a feminist geopolitical imaginary; it is necessary but insufficient.

Where critical geopolitics proves weakest, feminist geography galvanizes its radical political aims. Critical geopolitics exposes and interrogates the power relations embedded in dominant geopolitical narratives, but it largely fails to articulate other, more embodied ways of seeing. Without a feminist sensibility, critical geopoliticians are left with well-interrogated categories and a politicized approach to analysis, but no clear way forward in terms of political practice.

\section{Feminist approaches to IR}

The work of feminists in IR and geography is foundational to the project of feminist geopolitics. Kofman and Youngs (1996) collection represents an important collaboration across disciplines, and between feminist and political sensibilities. While a comprehensive discussion of the relevant and sizeable feminist IR literature is precluded here, the works of authors such as Pettman $(1996,1997)$, Peterson (1992, 1996), Kofman and Youngs (1996), and Tickner (2001) are central to thinking across the political geography/feminist geography divide. "[M]uch IR writing remains disembodied. The writers and their subjects do not have (visible) bodies" (Pettman, 1997: p. 95). Feminist and poststructuralist readings of geopolitics, like those of critical geopolitics, question not only the epistemological stakes, but also the dominant categories of analysis. "Part of the task of critical geopolitics is the investigation of the (territorial) construction of political community and the exploration of the possibilities of constructing forms of political communities which are not so vulnerable to the violence of sovereignty" (Dalby, 1994: p. 606). Feminist critiques of security have long challenged the tacit territorial assumptions of states by asking whether states actually render their populations secure (see Peterson, 1992). If citizenship is asymmetrical in practice (Pateman, 1989), then the security of nationals within the territorial borders of the state is also likely to be asymmetrical. Aboriginal groups, minorities, and migrants with different legal status enjoy or endure different degrees of security often within the same state.

Feminists in IR have hotly debated realist notions of security, noting that the limitations of binary Western metaphysics embedded therein also limit broader understandings of security. "Feminists are suspicious of statist ontologies that define security in zero-sum terms with binary distinctions between anarchy and order" (Tickner, 2001: p. 61). Despite the common practice of deconstructing dominant geopolitical discourse in critical geopolitics, feminist geopolitics aims to expose the disembodiment inherent in non-feminist poststructuralist critique: 
Whereas postmodernist critiques are alike in exposing the domination dynamics of a binary metaphysics, feminist postmodernists expose the essentializing, instrumentalist move at the core of this metaphysics ... Without destabilizing the fundamental dualism of "gender difference" (essentialized sexual identities), nonfeminist postmodernists effect a reinscription of the universal-particular (identity-difference) problematic as exclusively oppositional; they retain rather than transgress the oppressive boundary-systems of Western metaphysics (Runyan \& Peterson, 1991: pp. 76-77; emphasis added).

These feminist political scientists, not unlike critical geopoliticians, aim to expose the tacit norms of dominant discourse. Dualisms beyond that of gender fall prey to a similar critique, highlighting common terrain between these literatures.

Tickner adds that many feminists in IR, like those in critical security-studies, define security more broadly, "as the diminution of all forms of violence, including physical, structural and ecological" (Tickner, 2001: p. 62). The more policy-based concept of "human security" builds on this idea and has circulated over the last decade in UN organizations and governments that attempt to underscore human rights violations within sovereign states and build legitimacy for international interventions to address insecurity when a government is unwilling or unable to provide protection. Human security, in theory, disaggregates the broader notion of security to a finer scale at which smaller political constituencies and vulnerable groups become visible and their security a public matter of concern (Hyndman, 2001). Definitions vary from a narrow concept of freedom from fear for one's life to a broad rights-based understanding of security as freedom from the consequences of conflict that include poverty, lack of basic services, environmental degradation and the like. While the narrow concept of human security is most relevant to this discussion, Sylvester (1994) argues that security is a process of contentious struggle by people, not states. It is the focus of feminist geopolitics at multiple scales that include, I contend, the state.

Geographer Eleonore Kofman imagines a feminist geopolitics that would incorporate feminist analyses and gender into an extant set of geopolitical practices.

The most successful incorporation of feminist insights and gender issues into geopolitics would dismantle and democratize geopolitics such that it no longer involved the personnel of statecraft located with the most repressive echelons of the state. Real groups would then begin to figure in the landscapes and maps of the global economy and power relations. Geopolitics would open out into a broader context which we could call global political geography, in which comparative analyses and the local, however, that is defined, would also be included (Kofman, 1996: p. 218).

Her description of feminist geopolitics aspires to a more democratic and less punitive version of state-centric realist geopolitics. She also tacitly identifies a gap in the geographical literature: that the scale at which security is generally conceptualized precludes collective concerns, civil groups, and individual protection. I aim to extend and animate the feminist imagination Kofman articulates by 
suggesting that a feminist geopolitical analytic need not only dismantle the dominant discourse of geopolitics but subvert, shift, and animate the geographically specific narratives of particular groups.

Just as critical geopolitics should not be understood as a general theory of geopolitics or an authoritative intellectual negation of it, neither is feminist geopolitics about ushering in a new order of space. Whereas feminist critiques of IR query the primary categories of analyzing difference, critical geopolitics disputes the taken for granted containers into which geopolitics are poured (Weber, 1994). Both approaches implicitly or explicitly question the scale at which power is negotiated and inscribed. Developing a feminist geopolitical analytic is an important step towards reordering the conventions of security. Michael Shapiro (1996) addresses this issue, albeit only partially, in the critical geopolitics literature by distinguishing between strategic and ethnographic perspectives of mapping cultures of war. Neo-realist strategic perspectives deepen identity attachments and formal boundaries by treating them as "real" whereas ethnographic approaches aim to dethrone such takenfor-granted attachments by questioning the boundary-making narratives through which they are shaped. Through ethnographic perspectives embedded identities and strategic ways of seeing conflict and its consequences can be undone. Whereas critical geopolitics relies on ethnographic approaches, feminist geopolitics relies on both ethnographic and strategic approaches to enact other identity attachments and boundary-making narratives.

An example of strategic politics that at once undoes authoritative discourse and remakes it is the work of the Subaltern Studies group. This school of radical Indian history aims to unravel official Indian history by particularizing its story. As Spivak notes, it is "a strategic use of positivist essentialism in a scrupulously visible political struggle" (cited in Landry \& MacLean, 1996: p. 214). In order to transform the prevailing discourse of the day, one must critically engage in "strategic essentialism" from time to time. Coined by Spivak, this refers to making normative political commitments at crucial junctures. While Spivak (1996) does invoke primarily textual political strategies, as bricoleur she draws strategically from theoretical and political locations (including Marxism, feminism, and poststructuralism) to address questions of material violence and epistemological violence.

\section{Transnational feminist studies}

Like advocates of critical geopolitics, scholars of transnational feminist theory and postcolonial feminism have long sought to take apart, rather than oppose or amend, dominant political frameworks (McEwan, 1998; Alarćon, Kaplan, \& Moallem, 1999). The deconstruction of dominant intellectual traditions and practices, particularly by feminists, has proven useful in exposing hegemonic spatial imaginations and in analyzing the construction of gendered regimes of power vis-à-vis cultural norms, the state, and colonial power relations. This heterogeneous literature is characterized by feminist poststructuralist and postcolonial approaches that seek to recover the agency of marginalized peoples, and illustrate the ways in which particular groups are constructed in subordination. As Mouffe (1992: p. 382) notes 
Feminism, for me, is the struggle for the equality of women. But this should not be understood as a struggle for realizing the equality of a definable empirical group with a common essence and identity, women, but rather as a struggle against the multiple forms in which the category "woman" is constructed in subordination.

Feminist thought, however, does not limit itself to "woman" as the principal subject or axis of unequal power relations. Its greatest strength is that it analyzes the constitution and location of the subject as the basis of knowledge production. This positioning implies responsibility for practices of seeing and doing (Haraway, 1991): "there is no independent position from which one can freely and fully observe the world in all its complex particulars" (Barnes \& Gregory, 1997: p. 20). Epistemology is embodied.

The use of a transnational approach in this literature, according to its proponents, unsettles binary conceptions of politics as either global or local, central or peripheral, focusing instead on the circulation of power, identity, and subjectivity across space vis-à-vis transnational populations (Grewal \& Kaplan, 1994). Location includes, but is not limited to gender positionings and geographical place. It implies dimensions of power and identity that contribute to the very constitution of people and places as subjects. By deconstructing conventional political borders, Grewal and Kaplan (1994) advocate a discursive space more culturally attuned to poststructural analysis of disparities among transnational subjects heretofore largely ignored by geographers and political scientists. The title of their collection, Scattered Hegemonies, signals an interrogation of the state as but one conception and approach to understanding disparate power relations. Nationality, gender, religion, class, caste, age, nation, ability, and sexuality constitute disparate locations within a web of relationships that transcend political borders. Theirs is a world connected across borders, but characterized more by cultural difference and economic inequality than by political conflict or environmental destruction.

Each of these discrete theoretical literatures-critical geopolitics, feminist IR, and transnational feminist studies - offers insights and analyses, which together provide a basis for a feminist geopolitical analytic. Critical geopolitics takes apart dominant discourses of geopolitics, exposing to us that they are created, not given. Feminist critiques in transnational/cultural studies and IR question the scale at which security is conceived. Building on this well-interrogated terrain, feminist geopolitics comprises an embodied view from which to analyze visceral conceptions of violence, security, and mobility.

\section{From theory to practice}

Two interrelated analytical practices provide entry points for research related to feminist geopolitics. First, by redefining scales to employ analyses both finer and coarser than that of the nation-state and global economy, different epistemologies are produced and subjects analyzed. This approach imputes a new understanding 
of transnational as not only relations that traverse political borders, but as scales of analysis both coarser and finer than the nation-state. Second, by employing the body as both the subject and object of geopolitics, a different scale and measure of "security" is forged. The following section speaks to how feminist geopolitics is done.

\section{Rescaling geopolitical landscapes}

Critical analysis of mobility at multiple scales opens up a space for developing common ground between feminist politics and political geography. Redefining scale changes the geometry of social and political power. Swyngedouw (2000: p. 70) notes that the "continuous reshuffling and reorganizations of spatial scales are an integral part of social strategies and struggles for control and empowerment." Elsewhere, I employ the notion of a "geopolitics of mobility" to argue that international borders are more porous to capital than to displaced migrants, specifically refugees. The geopolitics and movement of international aid stand in contrast to relative immobility and weak geopolitical value of migrants (Hyndman, 1997). Mobility, traced at the finest of scales, is always constrained (Mitchell, 1997). People's mobility varies tremendously across axes of race (Tesfahuney, 1998), gender and class (Massey, 1993). It is also shaped, however, through the network of institutional and state practices that manage migration and access to it.

The geopolitics of mobility relates directly to access. For Somalian, Ethiopian, and Sudanese refugees in remote Kenyan camps, access to visa posts in the region is a crucial step towards possible resettlement in a third country. Applications for refugee resettlement to Australia and Canada, for example, must be made at the high commissions for each state, located in Nairobi. The refugee camps, where prospective refugee applicants live temporarily, are roughly $6 \mathrm{~h}$ away by bus. Only those with the money and the time to make the trip can apply. The vast majority of refugee women in the camps are solely responsible for child care, food preparation, water, food, and firewood collection, and other labour-intensive household tasks. They cannot simply leave these responsibilities for days at a time. Moreover, few have the funds to purchase a bus ticket to Nairobi, let alone to afford an overnight stay and related expenses. Their constrained mobility and limited access to the gateways of emigration shape their resettlement options (Hyndman, 2000).

Speaking of feminist geopolitics in another context, Smith (2001: p. 231) calls for a rescaling of geopolitics, "insisting on the need to repopulate the geopolitical landscape of the post-Cold War period and of "transition" [from East to West] with the gendered individuals and groups who, in their everyday lives, create, appropriate and challenge geopolitical discourse and practice at a whole variety of scales..." Smith outlines how women of the former [East] German Democratic Republic resisted western models of the gender division of labour, and agitated for child care provision after reunification. She illustrates how their particular combination of work and motherhood represent key parts of their femininity, a femininity that is quite distinct from their West German female counterparts. Smith (2001: p. 213) also invokes the concept of "human security" in relation to geopolitics, 
arguing for "cross-scale interactions of state, nation, economy, polity, family and the embodied (gendered) subject." Human security potentially transposes security discourse to a finer scale at which smaller political constituencies and less powerful groups become visible and their freedom from fear a public matter of concern. The threat of sexual violence against women, for example, serves to restrict their mobility (Valentine, 1992). Like human security, local ethnographies of fear engage security more viscerally (Pain, 2000). In practice, however, human security may also be used as a rationale for international intervention into the affairs of sovereign states not solely for the purpose of protecting people's fundamental human rights. Threats of forced migrants spilling over into adjacent states, for example, from Kosovo, have led to international interventions in the name of human security, but not necessarily just to protect the rights of potential refugees.

Threats of diseased bodies, social chaos, and impending out-migration due to violent conflict in developing regions represent an embodied, if xenophobic, geopolitics of fear and loathing (Kaplan, 1994a, 1994b; see Dalby, 1996 for critique). Alarmist accounts of conflict between civilizations and subsequent poverty, disease, and unwanted migration underscore a discourse of fear about "other" cultures, as if these are spatially separate and hermetically sealed off from one another (Huntington, 1998 for critique). Exposing the power relations that produce this dominant discourse, as critical geopolitics has done, is crucial. The next step is to examine the ways in which migrants-perceived as real and potential threats-are managed through such policies, and further to document the ways in which such policies help or hinders the security of migrants in receiving countries. Feminist geopolitics resists the mobilization of castigated bodies as mere vectors of disease, crime, and conflict, instead insisting on more accountable, material geographies of security and mobility.

\section{Grounding geopolitics: embodied geographies of war and mobility}

How and by whom is a feminist geopolitics enacted? As noted in my discussion of Ó Tuathail's (1996a) Critical Geopolitics, the author published an article the same year that elucidates an example beyond the fray of the disembodied, masculinist critical geopolitician. Referring to "an anti-geopolitical eye", Ó Tuathail (1996b: p. 171) assesses the journalism of Maggie O'Kane as a "way of seeing that disturbs the enframing of Bosnia in Western geopolitical discourse as a place beyond our universe of moral responsibility." That is to say, Bosnia is within our realm of responsibility and intervention as both commentators and people who stand against violence heaped upon the bodies of civilians.

I propose the notion of an "anti-geopolitical eye" not as a distinct alternative way of seeing Bosnia that transcends the geopolitical...[but] an eye that... persistently transgresses, unravels and exceeds the frameworks of scripting Bosnia in Western geopolitical discourse (Ó Tuathail, 1996b: p. 173).

In Ó Tuathail's words, O'Kane's reports are "direct", "personal", "moral", and "angry". In other words, the reports are politically engaged in relation to her 
audience with whom she "establishes a moral proximity" (ibid, p. 175). Her dispatches are not simply seen as displacing a dominant gaze, but of engaging politics at strategic moments whereby O'Kane becomes part of the script that she creates.

"Moral proximity" is an odd phrase to choose in describing political intervention or attempts to transform the geopolitical landscape. It implies a tainted process, one of bias or exaggeration in reporting that stands in contrast to a seemingly disembodied critical geopolitics. When coupled with "angry" and "personal", moral appears to be part of an emotional lexicon inappropriate to critical geopolitics. This serves to denigrate O'Kane's work in a subtle way, and to distance critical geopolitics from her involvement in the stories she presents. I contend that the concept of "moral" substitutes for politics that require ontological commitments and "taking sides," to borrow Routledge's (2002) turn of phrase. O'Kane uses the experience of ordinary people as the central register for recording highly personal stories of war in which she names and details the appearance of the people she meets and the scenes of violence she encounters (Ó Tuathail, 1996b). In effect, she politicizes and protests violence by invoking the particularities of people affected by the conflict. To my mind, this is an intentional tactic to mobilize her audience to "do something". O'Kane advocates action to curb what is depicted as senseless violence by publishing letters to the British Prime Minister in her column. While not without its critics, such journalism is inseparable from a social or political movement to stop militarized nationalism and conflict in Bosnia. It is too easy to distance oneself from the messiness of "moral" affairs, as Ó Tuathail tends to do in writing about O'Kane. If one replaces "moral" with "political", the bricks and mortar of a feminist geopolitics emerge. Ó Tuathail's argumentation is eloquent, especially when he notes that O'Kane is writing as much about us as about Bosnia. To the extent that O'Kane 'strengthened the West's response-ability towards Bosnia" (Ó Tuathail, 1996b: p. 182), she enacts a feminist geopolitics.

Geopolitics has become increasingly accountable to the security of women's bodies through new codification in the rules of war and their adjudication in the international legal system, specifically by the two War Crimes Tribunals for the Former Yugoslavia and Rwanda. In June 1996, for the first time, the tribunal for Yugoslavia prosecuted rape as a weapon of war and a "crime against humanity" (Kirshenbaum, 1997: p. 64). It issued indictments for the arrest of eight men, charged with sexual assault for the purposes of torture and enslavement. Ample evidence that men used rape to terrorize, humiliate, and contaminate the women of opposing ethnic groups in Bosnia-Herzegovina led to the indictments. "To rape women with impunity and to mark their bodies with the symbols of the other side is to assert domination and to symbolically assault ethnic identity in its most protected space" (Coomaraswamy, 1999: p. 10). People's bodies are construed as territory or property. They become public sites of violence on which constructions of the nation and its boundaries take place, and are therefore, of central concern to feminist geopolitics.

The ruling is significant not because it provides a punitive response to systematic violence, but because it renders sexual violence visible as a weapon of war. Sexual violence and rape may be "as old as war itself," but until now these issues have 
been rendered invisible or incidental: dismissed as private acts, the "aberrational practices of errant soldiers" (Coomaraswamy, 1999: p. 3). The tacit theatre of war was the battlefield, the public space around which the rules of war - the Geneva Conventions-have been written into existing international legal discourse. The public/private divide between the battlefield and civilian bodies has long dissolved. People's bodies, homes, communities, and livelihoods have become the battlefields of contemporary conflict. Rape is not simply an addition to international humanitarian and human rights law. It represents a new category of crime that reorganizes the scale and scope of punishment.

Feminist geopolitics prescribes no single political program or philosophical treatise. Rather, it aims to expose the pitfalls of dominant geopolitical discourse in concert with critical geopolitics. Political transformation often demands "taking sides" as Maggie O'Kane did during the war in Bosnia. Her visceral reportage points to embodied ways of seeing war, witnessing and protesting violence. Her modes of apprehension leave little room for ambivalence or apathy. At another scale, international legal interventions on the rules of war have generated highly embodied understandings of security of property, territory, nation and their transgression.

\section{Concluding remarks on a nascent project}

This paper has argued for a analytics of feminist geopolitics that is accountable to the care of bodies, one that shifts scales to include the security of state but in relation to the security and well-being of people who live in and across its borders. From the disembodied space of neo-realist geopolitics, and critical geopolitics, to the historically and geographically situated condition of peripheral subjects, a feminist geopolitics promulgates a multi-scalar approach to analyzing power relations. While the state remains an important subject of study in relation to security, it obscures issues of protection and freedom from violence at other scales, beyond the purview of the state. According to feminist IR and critical geopolitics, security is not principally about states. Rather it is a contentious process that is at once elusive and partial (Sylvester, 1994).

Feminist geopolitics does not promote a new theory of geopolitics; it does not usher in a new order of space, nor advocate an alternative universal standard of practice. Instead, it situates knowledge and spatializes conventions of "security" across scales. Drawing on the theoretical literature of critical geopolitics, feminist IR, and transnational feminist studies, feminist geopolitics asks, "security for whom and how?" To this deconstructionist and disembodied impulse, it insists upon a reconstructive but not universal basis for knowledge production and action. By redefining scale and tracing the security and mobility of migrant bodies, among others, feminist geopolitics-at a minimum-traverses the gap between feminist and political geography. At most, it promises more accountable renderings and actions at the intersection of geography and politics. 


\section{Acknowledgements}

I would like to thank the editors of this special issue and of the journal as well as three anonymous referees for their comments on this manuscript. Many others asked difficult questions and offered suggestions to improve it. I am especially indebted to Matt Sparke, Vicky Lawson, Eleonore Kofman, and Lynn Staeheli who all provided feedback on the paper. I am also grateful to the Social Science and Humanities Research Council of Canada for its support of this research program. All errors and shortcomings remain my own.

\section{References}

Agnew, J. (2003). Geopolitics: re-visioning world politics. (2nd ed.). London: Routledge.

Alarćon, N., Kaplan, C., \& Moallem, M. (1999). Introduction: between woman and nation. In C. Kaplan, N. Alarćon, \& M. Moallem (Eds.), Between woman and nation: nationalisms, transnational feminisms, and the state (pp. 1-16). Durham, NC: Duke University Press.

Anzaldua, G. (1987). Borderlands: the new mestiza. San Francisco: Spinster/Aunt Lute Press.

Barnes, T. J., \& Gregory, D. (1997). Worlding geography: geography as situated knowledge. In T. J. Barnes, \& D. Gregory (Eds.), Readings in human geography: the poetics and politics of inquiry (pp. 13-26). London: Arnold.

Coomaraswamy, R. (1999). A question of honour: women, ethnicity, and armed conflict, third minority rights lecture, May 25, Hotel Intercontinental, Geneva, Switzerland.

Dalby, S. (1991). Critical geopolitics: discourse, difference, and dissent. Environment and Planning D: Society and Space, 9, 261-283.

Dalby, S. (1994). Gender and critical geopolitics: reading security discourse in the new world order. Environment and Planning D: Society and Space, 12, 595-612.

Dalby, S. (1996). The environment as geopolitical threat: reading Robert Kaplan's "Coming Anarchy”. Ecumene, 3(4), 472-496.

Dalby, S. (2003). Codes, vision, knowledge: the reasoning practices of critical geopolitics. Paper presented to the Canadian Association of Geographers, Victoria BC, May.

Dowler, L., \& Sharp, J. (2001). A feminist geopolitics? Space and Polity, 5(3), 165-176.

Falk, R. (2000). Human rights horizons: the pursuit of justice in a globalizing world. New York: Routledge.

Grewal, I., \& Kaplan, C. (1994). Introduction: transnational feminist practices and questions of postmodernity. In I. Grewal, \& C. Kaplan (Eds.), Scattered hegemonies: postmodernity and transnational feminist practices (pp. 1-33). Minneapolis: University of Minnesota Press.

Haraway, D. (1991). Situated knowledges. Simians, cyborgs, and women: the reinvention of nature (pp. 183-201). New York: Routledge.

Huntington, S. (1998). The clash of civilizations? (originally published in Foreign Affairs, 1993). (Reprinted in Ó Tuathail, G., Dalby, S., \& Routledge, P. The Geopolitics Reader. New York: Routledge, pp. 159-169).

Hyndman, J. (1997). Border crossings. Antipode, 29(2), 149-176.

Hyndman, J. (2000). Managing displacement: refugees and the politics of humanitarianism. Minneapolis: University of Minnesota Press.

Hyndman, J. (2001). Towards a feminist geopolitics. The Canadian Geographer, 45(July (2)), 210-222.

Kaplan, C. (1994a). The politics of location. In I. Grewal, \& C. Kaplan (Eds.), Scattered hegemonies: postmodernity and transnational feminist practices (pp. 137-152). Minneapolis: University of Minnesota Press.

Kaplan, R. (1994b). The coming anarchy: how scarcity, crime, overpopulation, and disease are rapidly destroying the social fabric of our planet. Atlantic Monthly, February, 44-76. 
Kaplan, C., Alarćon, N., \& Moallem, M. (Eds.) (1999), Between woman and nation: nationalisms, transnational feminisms, and the state. Durham, NC: Duke University Press.

Kirshenbaum, G. (1997). Jadranka Cigelj and Nusreta Sivac: efforts to bring the rapists of Bosnian women to justice. Ms., 7(4), 64-68.

Kobayashi, A., \& Peake, L. (1994). Unnatural discourse. 'Race' and gender in geography. Gender, Place and Culture, 1(2), 225-249.

Kofman, E. (1996). Feminism, gender relations and geopolitics: problematic closures and opening strategies. In E. Kofman, \& G. Youngs (Eds.), Globalization: theory and practice (pp. 209-224). London, New York: Pinter.

Kofman, E., \& Peake, L. (1990). Into the 1990s: a gendered agenda for political geography. Political Geography Quarterly, 9, 313-336.

Kofman, E., \& Youngs, G. (1996). Globalization: theory and practice. London, New York: Pinter.

Landry, D., \& MacLean, G. (1996). The Spivak reader: selected works of Gayatri Chakravorty Spivak. New York: Routledge.

Massey, D. (1993). Power-geometry and a progressive sense of place. In J. Bird, B. Curtis, T. Putnam, G. Robertson, \& L. Tickner (Eds.), Mapping the futures: local cultures, global change (pp. 59-69). New York: Routledge.

McEwan, C. (1998). Dismantling the master's house'?: towards a postcolonial geography. Criticalgeography-forum-online (accessed January 8, 2002 at http://www.jiscmail.ac.uk/files/CRIT-GEOGFORUM/mcewan.htm), posted Sept. 11 .

Mitchell, K. (1997). Transnational discourse: bringing geography back in. Antipode, 29(2), 101-114.

Mohanty, C. T. (1991). Under Western eyes. In C. T. Mohanty, A. Russo, \& L. Torres (Eds.), Third world women and the politics of feminism. Bloomington, Indianapolis: University of Indiana Press.

Mouffe, C. (1992). Feminism, citizenship, and radical democratic politics. In J. Butler, \& J. Scott (Eds.), Feminists theorize the political (pp. 369-384). New York, London: Routledge.

Ó Tuathail, G. (1996a). Critical geopolitics. Minneapolis: University of Minnesota.

Ó Tuathail, G. (1996b). An anti-geopolitical eye: Maggie O'Kane in Bosnia, 1992-93. Gender, Place and Culture, 3(2), 171-185.

Ó Tuathail, G. (1998). Political geography III: dealing with deterritorialization. Progress in Human Geography, 22(1), 81-93.

Pain, R. (2000). Place, social relations and the fear of crime: a review. Progress in Human Geography, 24(3), 365-387.

Pateman, C. (1989). The disorder of women: democracy, feminism and political theory. Cambridge: Polity.

Peterson, V. S. (1992). Security and sovereign states: what is at stake in taking feminism seriously. In V. S. Peterson (Ed.), Gendered states: feminist (re)visions of international relations theory. Boulder, CO: Lynne Rienner.

Peterson, V. S. (1996). Shifting ground(s): epistemological and territorial remapping in the context of globalization(s). In E. Kofman, \& G. Youngs (Eds.), Globalization: Theory and Practice (pp. 11-28). London, New York: Pinter.

Pettman, J. J. (1996). Worlding women: a feminist international politics. London, New York: Routledge.

Pratt, G. (2000). Feminist geographies. In R. J. Johnston, D. Gregory, G. Pratt, \& M. Watts (Eds.), The dictionary of human geography (4th ed.) (pp. 259-262). Oxford, Malden, MA: Blackwell Publishers.

Routledge, P. (1996). Critical geopolitics and terrains of resistance. Political Geography, 15(6-7), 509-552.

Routledge, P. (2002). Travelling east as Walter Kurtz: identity, performance and collaboration in Goa, India. Environment and Planning D: Society and Space, 20, 477-498.

Runyan, A. S., \& Peterson, V. S. (1991). The radical future of realism: feminist subversions of IR theory. Alternatives, 16, 67-106.

Shapiro, M. (1996). Cartographies of struggle: mapping cultures of war. Minneapolis: University of Minnesota Press.

Sharp, J. (1996a). Hegemony, popular culture and geopolitics: the Reader's Digest and the construction of danger. Political Geography, 15(6/7), 557-570. 
Sharp, J. (1996b). Gendering nationhood: a feminist engagement with national identity. In N. Duncan (Ed.), Bodyspace: destabilising geographies of gender and sexuality (pp. 97-108). New York, London: Routledge.

Sharp, J. (2000a). Remasculinising geo-politics? Comments on Gearoid O'Tuathail's critical geopolitics. Political Geography, 19, 361-364.

Sharp, J. (2000b). Condensing the Cold War. Minneapolis: University of Minnesota Press.

Smith, F. (2001). Refiguring the geopolitical landscape: nation, "transition" and gendered subjects in post-Cold War Germany. Space and Polity, 5(3), 213-235.

Sparke, M. (1996). Negotiating national action: free trade, constitutional debate and the gendered geopolitics of Canada. Political Geography, 15(6/7), 615-640.

Sparke, M. (1998). The map that roared and an original Atlas: Canada, cartography, and the narration of nation. Annals of Association of American Geographers, 88(3), 463-495.

Sparke, M. (2000). Graphing the geo in geo-political: critical geopolitics and the re-visioning of responsibility. Political Geography, 19, 373-380.

Spivak, G. C. (1996). In D. Landry, \& G. MacLean (Eds.), The Spivak reader: selected works of Gayatri Chakravorty Spivak. New York: Routledge.

Spivak, G. C. (1990). Postmarked Calcutta, India. In S. Harasym (Ed.), The postcolonial critic: interviews, strategies, dialogues (pp. 75-90). New York: Routledge.

Staeheli, L. (1994). Empowering political struggle: spaces and scales of resistance. Political Geography, 13(5), 387-391.

Staeheli, L. (1999). Tyrannies of indifference: feminist and political geographies. Presentation to the American Association of Geographers Annual Conference, Honolulu, Hawaii, March (mimeo).

Staeheli, L., Kofman, E., \& Peake, L. (Eds.). (2004). Mapping women, making politics. New York/ London: Routledge.

Sylvester, C. (1994). Feminist theory and international relations in a postmodern era. Cambridge, England, New York: Cambridge University Press.

Swyngedouw, E. (2000). Authoritarian governance, power, and the politics of rescaling. Environment and Planning D: Society and Space, 18, 63-76.

Taylor, P. (2000). Critical geopolitics. In R. J. Johnston, D. Gregory, G. Pratt, \& M. Watts (Eds.), Dictionary of human geography (pp. 125-126). Oxford, Malden, MA: Blackwell.

Tesfahuney, M. (1998). Mobility, racism and geopolitics. Political Geography, 17, 499-515.

Tickner, J. A. (2001). Gendering world politics: issues and approaches in the post-Cold War era. New York: Columbia University Press.

Valentine, G. (1992). Images of danger: women's sources of information about the spatial distribution of male violence. Area, 24(1), 22-29.

Weber, C. (1994). Shoring up a sea of signs: how the Caribbean Basin initiative from the US invasion of Grenada. Environment and Planning D: Society and Space, 12(5), 547-560.

Whitworth, S. (1994). Feminism and international relations: towards a political economy of gender in multilateral institutions. Houndmills, Basingstoke, Hampshire: Macmillan. 